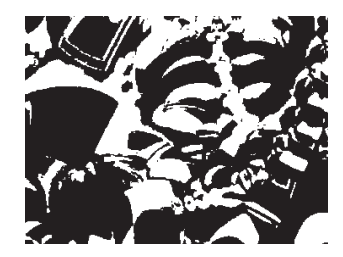

\title{
CHARACTERISTICS AND DETERMINANTS OF INTERGENERATIONAL FINANCIAL TRANSFERS WITHIN FAMILIES USING MIXED CARE FOR ELDERLY PEOPLE
}

Valentina HLEBEC, Maša FILIPOVIČ HRAST

Faculty of Social Sciences, Ljubliana

$\begin{aligned} \text { UDK: } & 316.362 .1: 364(497.4) \\ & 364.614 .2-053.9(497.4) \\ & 173.7\end{aligned}$

Izvorni znanstveni rad

Primljeno: 23. 4. 2017.

The authors acknowledge the financial support from the Slovenian Research Agency (research core funding No. P5-0200 and project funding J5-8235).

The provision of care to dependent elderly parents or parents-in- law is an important part of intergenerational exchange within families, especially in countries where the long-term care system is based predominantly on family care. However, in mixed-care networks, care tasks are shared between family members and formal carers. Additionally, adult children may need to financially help their parents, especially due to the financial burden that formal care places on the elderly. We used the Slovenian national survey of social home care users and their family members, collected in 2013 , to observe the characteristics and determinants of intergenerational financial transfers in families that use mixed care, within dyads comprising a care recipient and a family caregiver. The findings show that there is a considerable proportion of financial exchange among the observed dyads. Furthermore, among the determinants, the income of the elderly person and amount of care received are important for financial flows upward (to the elderly parent) and downward (from the elderly parent). The concurrent flows differ; their main determinants are the carer's age, household size and education.

Keywords: intergenerational solidarity, family, financial transfers, social home care

$\triangle \quad$ Valentina Hlebec, University of Liubliana, Faculty of Social Sciences, Kardeljeva ploščad 5, 1000 Ljubljana, Slovenia. 
The aging of the population has demanded a new emphasis on welfare states in all European countries to address this issue and develop new services or broaden existing ones for the elderly in order to ensure their quality of life. However, there are significant differences among countries in the roles that formal services and family play in the provision of care for the elderly. In the literature, these differences have been labelled as variations in care regimes or varieties of familialism (Saraceno \& Keck, 2010; Motel-Klingebiel, Tesch-Roemer, \& Von Kondratowitz, 2005; Bettio \& Plantenga, 2004; Leitner, 2003). Slovenia, as one of the Central and Eastern European (CEE) countries, has been positioned as belonging to the familialistic model (Hlebec, Nagode, \& Filipovič Hrast, 2014a; Hlebec, Nagode, \& Filipovič Hrast, 2014b; Hlebec, Srakar, \& Majcen, 2016) in which the family has traditionally been the main provider of care for the elderly. The traditional approach to care in such a familialistic model is that of the family providing care for the elderly as long as possible, and when the need for care becomes too great for the family to meet it, institutional care is chosen. Social home care services, which can represent an important complement to family care, developed slowly after the 1990s and spread; however, their growth stalled with the recession (Hlebec et al., 2014 a, b; Nagode, Lebar, Kovač, \& Vidrih, 2016; Hlebec \& Filipovič Hrast, 2016). This development is similar to that in the CEE region, e.g., in Croatia, the 1990s were marked by a pluralisation of service providers and the beginnings of the decentralisation and professionalisation of non-institutional forms of care. However, the services retain a residual character (Dobrotić, 2016).

The role of family carers who use formal care services has not been sufficiently researched in Slovenia, especially the role they have in co-financing formal care and how this is interlinked with informal provision of care. Such knowledge is vital for the development of social home care services, for it would enable not only a better quality of life for the elderly person using these services but also for the family carer. It is therefore vital to better understand the intergenerational relationship within families who use mixed-care arrangements because this improved understanding could guide policy-making and identify potential obstacles in the use of social home care services. Researching intergenerational financial transfers is relevant for better understanding the financial pressures that arise in both the caregiver's and care recipient's households when formal care services are used. This is particularly relevant due to the high proportion of poverty among the elderly in Slovenia and the relatively high cost of care services (Hlebec \& Rakar, 2017; Filipovič Hrast, Hlebec, \& Kavčič, 2012). 
DRUŠ. ISTRAŽ. ZAGREB GOD. 27 (2018), BR. 1 STR. $27-46$

HLEBEC, V., FILIPOVIČ HRAST, M.:

CHARACTERISTICS...
The aim of this article is to observe the characteristics and determinants of intergenerational financial transfers among families that use mixed care, i.e., a combination of formal and informal care for older people. The article therefore offers new insight into intergenerational transfers in the less-researched CEE context, where familialism exists and formal care is underdeveloped, by looking into financial transfers within families using a mixed model of care.

\section{BACKGROUND: CARE FOR THE ELDERLY IN SLOVENIA}

Slovenia belongs to the countries where the family is the main provider of care, and funding by the state for long-term care is low. It has been late in developing social home care services for the elderly who live in a community, but it has relatively well-developed institutional care for them. The social home care services began to develop, similarly to elsewhere in the region, in the 1990s. However, the number of users has risen relatively slowly, from 3,909 in 1998 up to 7,100 in 2015 (Hlebec \& Rakar, 2017). Social home care was established as a social protection service that is a part of the public social protection network, and the co-financing of the services by public works was introduced in that period. Along with the expansion and professionalisation of the service in the next decade, payment for users was introduced in 2000, and until 2011, the Ministry for Labour, Family and Social Affairs co-financed the service by contributing to the labour costs of the service provider (Nagode et al., 2016). The financial costs are currently partially covered by the municipality, which is obliged to cover at least $50 \%$ of the cost of the service. If users are unable to pay their share of the costs, family members are obliged to pay, and only in the case they are unable to pay, the users can apply for reduced payments (see Hlebec \& Rakar, 2017). However, the levels of subsidy differ across municipalities, resulting in significant variations in the cost of these services for the end users.

The use of home care services is limited to 4 hours of care per day or a maximum of 20 hours per week. The organisation of these services is regionalised, i.e., they are organised at the level of municipalities, who are therefore responsible for organising services and subsidising them. Most often, these services are provided by centres for social work or public homes for the elderly. Research has revealed significant variations between regions and municipalities in the availability and accessibility of these services (see Hlebec, 2010, 2012, 2014). During the recession, the number of users of social home care services began to stagnate and was, with $1.7 \%$ of the elderly $(65+)$ in 2015, below the policy target of serving $3 \%$ of the elderly population (Nagode et al., 2016). Researchers have noted that 
DRUŠ. ISTRAŽ. ZAGREB GOD. 27 (2018), BR. 1, STR. $27-46$

HLEBEC, V., FILIPOVIČ HRAST, M.:

CHARACTERISTICS... the costs of the services are too high (e.g., Hlebec, 2010, 2012, 2014; Hlebec et al., 2014 a, b).

Institutional care, in contrast to social home care, is relatively well developed with the number of homes as well as residents rising since the 1990s, from 53 homes with 11,260 residents in 1990 to 94 homes and 18,247 residents in 2015 . However, as shown by Hlebec and Rakar (2017), the average pension levels are below the average users' daily payments, indicating the frequently insufficient funds of the elderly to cover the financial costs of institutional care.

An important characteristic of Slovenia is the legal obligation for children to provide for their parents in case their income is insufficient. Consequently, children have a legal obligation to co-finance care services, either social home care or institutional care. There is little additional support for family carers. One such instrument is the home assistant, a family member who becomes a permanent carer who, in return, receives payment for lost income at the level of the minimum wage from the state.

Based on these characteristics, Slovenia can be labelled as having a care regime described as familalism by default, or implicit familialism, in which the support provided by the welfare state is minimal, and families are the main providers of care, which is a general characteristic for CEE countries and Southern European countries (see Leitner, 2003; Saraceno, 2010; Saraceno \& Keck, 2010). This is in stark contrast to non-familialistic care regimes, a characteristic of Scandinavian countries, where the welfare state is the main provider of care for the elderly, or supported familialisation (i.e., explicit familialism), in which the welfare state provides benefits to support families as the main providers of care (e.g., Austria and Germany). Therefore, the countries with implicit familialism are, in general, those with poorly developed community care services for the elderly, poorly developed formal care services and low availability of transfers (e.g., cash-for-care schemes) (see Broese van Groenou, Glaser, Tomassini, \& Jacobs, 2006; Künemund, 2008; Motel-Klingebiel et al., 2005; Jacobs, Broese van Groenou, de Boer, \& Deeg, 2014).

\section{LITERATURE REVIEW: FAMILY TRANSFERS AND THEIR DETERMINANTS}

There is a vast amount of literature on intergenerational relations and transfers (e.g., Bengtson \& Roberts, 1991; Bengtson \& Oyama, 2007; Szydlik, 2008). One of the influential theories is the theory of intergenerational solidarity developed by Bengtson and Roberts (1991), who have defined the following dimensions of solidarity: associational solidarity, affectual soli- 
DRUŠ. ISTRAŽ. ZAGREB GOD. 27 (2018), BR. 1 STR. $27-46$

HLEBEC, V., FILIPOVIČ HRAST, $M$.:

CHARACTERISTICS... solidarity and structural solidarity. In this article, we will focus on one dimension of solidarity, that is, functional solidarity, which denotes transfers within the family (such as financial transfers and emotional care tasks), looking in particular at financial transfers.

There are several determinants that influence financial transfers. Szydlik (2008) describes them in a comprehensive model related to all forms of solidarity, including functional solidarity, which is the focus in this article, and distinguishes between the following: opportunity structure (such as geographical proximity); needs structure (such as the financial and health care needs of the elderly); and family structure, or observation on the micro-level of the family. These are the main determinants of intergenerational transfers.

Albertini, Kohli, and Vogel (2007) looked specifically at financial transfers within families and found that the balance of financial transfers changes with the age of the elderly person; however, the net balance remains such that even the oldest group of the elderly are more often givers than receivers of financial transfers. Only a small percentage (less than $4 \%$ ) of the elderly receives financial transfers from their children. They also found that financial transfers from the old to the young are more common in those living as a couple, those with higher socio-economic status and education and those with good health. Mudrazija (2014) also showed that net transfers of money from parents to children only modestly decrease with age. Additionally, Fritzell and Lennartsson (2005) have found that within this clear downward flow of financial transfers, there is a class and income gradient as both giving and receiving are more common among people in the higher social strata. The research by Brandt and Deindl (2013) also showed that socioeconomic background influenced the frequency as well as the amount of transfers.

Additionally, the gender of the child and their age, sociodemographic characteristics and contact frequency were shown to influence financial transfers from the parent to the adult child (Leopold \& Raab, 2011). Researchers have, in general, confirmed that intergenerational transfers depend on the gender of the carer and of the parent, as women more often give and receive help within the family (Silverstein, Parrott, \& Bengtson, 1995; Silverstein \& Bengtson, 1997; Brandt, Haberkern, \& Szydlik, 2009; Litwin, Vogel, Künemund, \& Kohli, 2008). Also, needs have been shown to be one of the main determinants of transfers (Mudrazija, 2016; Litwin et al., 2008; Brandt \& Deindl, 2013). Additionally, family structure affects downward and upward transfers as siblings' influences compete for the resources of their parents (Brandt \& Deindl, 2013), while on the other hand, the care burden and transfers to the care recipient can 
DRUŠ. ISTRAŽ. ZAGREB GOD. 27 (2018), BR. 1, STR. $27-46$

HLEBEC, V., FILIPOVIČ HRAST, M.:

CHARACTERISTICS... also be shared among sibling caregivers and also experienced to a different degree (for an overview, see Carretero, Garcés, Ródenas, \& Sanjosé, 2008). An additional factor is also the family situation of the caregivers, which can add to the financial and caregiving burden. Friedman, Park, and Weimers (2015) showed that over 30\% of individuals with living parents and adult children provide time and financial transfers to both, and that these transfers are relatively stable across adult ages. Also, the income of caregivers is a relevant factor as lower-income caregivers are associated with higher subjective care burdens (Andren \& Emstahl, 2007).

Financial transfers from parents to children might also be a stimulant or reward for help from the children. There is an indication that reciprocity is significant as receiving social support from children increases the likelihood of returned financial transfer (Albertini et al., 2007; Brandt and Deindl, 2013). The findings of Lennartsson, Silverstein, and Fritzell (2010) similarly indicate that parents provide economic transfers if they have more frequent social contact with any of their children, and that these time investments pay off for children of higher social class origins. This is linked to social exchange theory and equity theory, which posit that flows between adult children and parents are based on the premise that social relationships are governed by a norm of reciprocity, that both search for balanced transactions and repayment of past transfers through their life courses and that balanced relationships enable higher well-being (Silverstein, Conroy, Wang, Giarrusso, \& Bengtson, 2002; Grundy, 2005; Lowenstein, Katz, \& Gur-Yaish, 2007). Transfer motives can range from pure altruism to paternalistic behaviour to self-interested strategic exchange, and these motives overlap and interact (Kohli \& Kunemund, 2003). Even though the focus of the majority of studies is on general, everyday types of exchanges and not on intensive care giving, Grundy (2005) suggests that these exchange principles could be generalised as they represent points on a continuum rather than distinct concepts and could therefore also be generalised to specific situations as in our article, where more intensive care is needed by the older people.

On the macro-level, structural and institutional characteristics (such as the welfare state and care regime); demographic structure; and cultural determinants, values and norms determine intergenerational family transfers (cf. Igel, Brandt, Haberkern, \& Szydlik, 2009; Szydlik, 2008; Albertini et al., 2007). Since our article does not have a comparative perspective, we will not focus on these macro-level determinants; however, one needs to point out that financial transfers are less common in countries with strong welfare states and developed social policies, which also enable more downward financial flows 
DRUŠ. ISTRAŽ. ZAGREB GOD. 27 (2018), BR. 1 STR. $27-46$

HLEBEC, V., FILIPOVIČ HRAST, $M$.:

CHARACTERISTICS... (from parents to children) (e.g., Björnberg \& Ekbrand, 2008; Deindel \& Brandt, 2011; Brandt \& Deindl, 2013; Mudrazija, 2016). Additionally, the decrease in downward transfers that is a characteristic of the increasing age of parents is slower in sociodemocratic countries than in Mediterranean countries (Mudrazija, 2014). Deindel and Brandt (2011) showed that financial transfers to parents were very rare in Europe as in only $2 \%$ of the dyads was money transferred upwards, while financial transfers from parents to children were more frequent, occurring in around $4 \%$ of the dyads. Financial support from parents to children is more likely in northern and Western Europe, affecting 9\% to $11 \%$ of dyads in Denmark and Sweden but less than $2 \%$ in Spain (Deindel \& Brandt, 2011). On the other hand, transfers from children to the elderly are more likely in Eastern Europe, affecting 3\% to 4\% of dyads in Poland (Deindel \& Brandt, 2011). As a part of the CEE region, Slovenia therefore makes an interesting research case where upward financial flows will be more likely. In Slovenia, the majority feel that it is the duty of the child to support their elderly parents in case of need, similarly to the majority of eastern European countries (see Hlebec et al., 2012), and, as noted, there is a legal obligation to financially support the parents in case of need. As Haberkern and Szydlik (2010) have shown, intergenerational support is more prevalent in Southern and Central European countries where children are legally obligated to support their parents in need.

\section{CONCEPTUAL FRAMEWORK}

Despite the considerable research that already exists on financial flows within families, there is little research on how families cope with the additional financial burden that presents itself when formal social home care is introduced in countries to which users are supposed to contribute substantially in order to meet the costs of the service. We can presume that, in general, the same determinants influence the financial flows between children and parents, and that therefore age, gender, income, need and family structure will influence financial transfers. It is less clear whether the amount and direction of these flows will follow the same patterns as described above, or whether, due to this additional financial burden, the flows and the direction of financial transfers will perhaps be reversed to upward flows. The main findings on financial transfers presented in the previous section indicate that downward financial flows are more common than upward financial flows. However, in accordance with the specifically researched population of social home care users in a familialistic country, we form an alternative hypothesis (H1) that upward financial flows will be more common than downward financial flows. 
DRUŠ. ISTRAŽ. ZAGREB GOD. 27 (2018), BR. 1, STR. $27-46$

HLEBEC, V., FILIPOVIČ HRAST, M.:

CHARACTERISTICS...
Of particular interest in this article are also the reciprocal patterns; that is, concurrent flows where transfers of money and time are exchanged simultaneously. This relates to the short-term reciprocity, or concurrent giving and receiving, as defined by Leopold and Raab (2011). They see this kind of simultaneous flows as a means to relieve the ambivalence of the older parent-child relationship and ease the feeling of dependency of the parents. They defined as key determinants for these simultaneous flows the need of the parent, financial means, care received, contact frequency, geographical proximity and the socioeconomic characteristics of the adult child. Their findings confirmed these determinants but also indicated that such concurrent flows are not common but are rather a rarity. Consequently, we can hypothesise that the share of the concurrent transfers will be the smallest $(\mathrm{H} 2)$.

The last hypotheses that we tested in this article focuses on the determinants of the transfer flows and their direction. A poorer financial situation of the parent will increase the chance for upward flows and reduce the chance of downward and concurrent flows (H3). We hypothesise that the larger amount of care given by the adult child will also increase downward financial flows and concurrent flows (H4) in accordance with the short-term reciprocity paradigm and findings of Albertini et al. (2007).

\section{EMPIRICAL ANALYSIS}

\section{Methodology}

The data for this study was collected in 2013 using a paper and pencil survey on a representative sample of recipients of social home care and their family carers (Hlebec et al., 2014b). The average response rate was $30 \%$, resulting in 1,057 completed questionnaires from family carers. The response rate is similar to the response rate for social home care users' surveys (Hlebec et al., 2014b). The realised samples correspond to the population data of social home care users by age and gender. These two characteristics are the only ones that are available from the population (Nagode et al., 2016). The information about family carers in our sample is comparable in sociodemographic characteristics to what is known about this population so far (e.g., Hlebec et al., 2014b; Hlebec et al., 2016). Out of all care dyads, 634 were intergenerational, i.e., adult children were providing care to parents or parents-in-law at least monthly. Only these dyads were taken into account in this study.

The dependent variable intergenerational financial transfer measures the existence of intergenerational financial transfers between adult children, who, apart from providing informal care for their dependent parents, may contribute financially to meeting the costs of formal social home care. Their parents 
DRUŠ. ISTRAŽ. ZAGREB GOD. 27 (2018), BR. 1 STR. $27-46$

HLEBEC, V., FILIPOVIČ HRAST, $M$.:

CHARACTERISTICS... may reciprocate the financial transfer either in the form of small gifts or money. This dependent variable therefore results in four values $(0=$ no financial transfer between generations; $1=$ downward financial transfer from parents to adult children who do not contribute financially to social home care but provide informal care; 2 = upward financial transfer from adult children to dependent parents; and $3=$ concurrent financial transfer between generations, where adult children contribute financially to meeting the costs of social home care and dependent parents repay the care received in some manner, either with gifts, financial contributions or by doing something in return).

Owing to the nominal nature of the dependent variable, multinomial regression analysis was chosen to assess the effects of independent variables on intergenerational financial transfers. Due to the small number of dyads in the analysis and the subsequent reduction of dyads included in the regression analysis because of partial nonresponses, the number of independent variables included in the final analysis was relatively small. We conducted a comparison between the original sample of 634 dyads to the sample of dyads used in the final regression analysis $(n=404)$. The characteristics of all variables included in the modelling have nearly identical statistical properties after comparing the initial sample of dyads and final sample included in the regression analysis. We initially included the same independent variables for family carer characteristics as we did for care recipient characteristics. Subsequently, we excluded all care recipient characteristics that were correlated (e.g. the correlation between carer's age and care recipient's age was 0.47 ) with the characteristics of family caregivers or had no significant influence on intergenerational financial transfer in order to prevent multi-collinearity and to simplify the model.

The final selection of independent variables measuring family caregivers' characteristics was as follows: gender $(0=\mathrm{fe}-$ male, $1=$ male), age (years), education $(0=$ vocational school or less, $1=$ high school or more), subjective perception of income using a proxy measure of difficulty of managing with family income $(0=$ can manage with the family income, $1=$ it is very difficult to manage with the family income), household size (i.e., number of people in household) and the intensity of family care (evaluated using a Likert index of 22 activities of daily living, measured on a five point scale ranging from 1 , never, to 5 , daily: individual categories being 1 , never; 2 , less often; 3, monthly; 4, weekly; and 5, daily). We treat the intensity of family care as a continuous variable given the frequency distribution. The subjective assessment of income was also evaluated for the care recipient household $(0=$ can manage 
with the family income, $1=$ it is very difficult to manage with the family income).

\section{Results}

We now turn to our descriptive results. Family carers were aged 55 on average and scored 2.9 on the care index. On average, the household size was 3 . The frequency distribution of other variable values is presented in Table 1.

\begin{tabular}{lrr}
\hline & $n$ & $\%$ \\
\hline Intergenerational financial transfer & & \\
0: No financial transfer between generations & 321 & 50.6 \\
1: Downward financial transfer from dependent parents to adult children & 136 & 21.5 \\
2: Upward financial transfer from adult children to dependent parents & 128 & 20.2 \\
3: Concurrent transfer & 49 & 7.7 \\
Gender & 396 & 63.0 \\
0: Female & 233 & 37.0 \\
1: Male & & \\
Education & 135 & 23.7 \\
0: Vocational school or less & 435 & 76.3 \\
1: High school or more & & \\
Income of caregiver's household & 433 & 79.4 \\
0: Can manage with the family income & 112 & 20.6 \\
1: It is very difficult to manage with the family income & & \\
Income of care recipient's household & 381 & 70.3 \\
0: Can manage with the family income & 161 & 29.7 \\
1: It is very difficult to manage with the family income & & \\
\hline
\end{tabular}

Note: All variables except care recipient income were reported by the caregiver.

(1) TABLE 1

Descriptive statistics of research variables
An important result of our analysis is the frequency of financial transfers between generations, as half of the respondents reported downward, upward or concurrent financial transfers. Upward financial transfer from children to parents occurred in $20.2 \%$ of the cases, which is a much higher rate of upward transfer than expected based on the previous research (Albertini et al., 2007; Deindl \& Brandt, 2011) on samples of a general population and not a specific population as is the case in this article. It indicates that in specific and financially burdensome circumstances, such as the need for social home care, children need to aid their parents financially for them to be able to afford such care. There was also a significant downward flow. Again, in about one fifth or $21.5 \%$ of the dyads, elderly parents made transfers to their children. Concurrent flows were found in $7.7 \%$ of the dyads; i.e., where both upward financial transfers from children for social home care services were found as well as downward flows from the elderly (either financially, with gifts or by doing something for the carer). 
Bivariate associations between the dependent and independent variables are reported in Table 2 and Table 3.

\begin{tabular}{|c|c|c|c|c|c|c|}
\hline & & & 0 & 1 & 2 & 3 \\
\hline Gender & & & & & & \\
\hline Female & & & $65,0 \%$ & $60,9 \%$ & $65,4 \%$ & $49,0 \%$ \\
\hline Male & & & $35,0 \%$ & $39,1 \%$ & $34,6 \%$ & $51,0 \%$ \\
\hline Education & & & & & & \\
\hline Vocational school or & & & $21,8 \%$ & $20,8 \%$ & $27,2 \%$ & $33,3 \%$ \\
\hline High school or more & & & $78,2 \%$ & $79,2 \%$ & $72,8 \%$ & $66,7 \%$ \\
\hline Income of caregiver's h & asehold & & & & & \\
\hline Can manage with th & family & & $83,1 \%$ & $78,9 \%$ & $70,3 \%$ & $83,7 \%$ \\
\hline It is very difficult to & anage $v$ & nily income & $16,9 \%$ & $21,1 \%$ & $29,7 \%$ & $16,3 \%$ \\
\hline Income of care recipier & house & & & & & \\
\hline Can manage with th & family & & $74,9 \%$ & $79,0 \%$ & $47,8 \%$ & $76,2 \%$ \\
\hline It is very difficult to & anage $v$ & nily income & $25,1 \%$ & $21,0 \%$ & $52,2 \%$ & $23,8 \%$ \\
\hline $\begin{array}{l}\text { (1) TABLE } 2 \\
\text { Bivariate associations } \\
\text { between the depen- } \\
\text { dent and independent } \\
\text { variables }\end{array}$ & $\begin{array}{l}0-\mathrm{N} \\
\text { cial tr } \\
\text { finan } \\
\text { curre }\end{array}$ & $\begin{array}{l}\text { transfer betwee } \\
\text { m dependent } p^{2} \\
\text { r from adult chi }\end{array}$ & $\begin{array}{l}\text { arents to } \\
\text { ldren to }\end{array}$ & $\begin{array}{l}\text { ns, } 1- \\
\text { lult chi } \\
\text { pender }\end{array}$ & $\begin{array}{l}\text { - Downwa } \\
\text { ildren, } 2 \text { - } \\
\text { nt parents }\end{array}$ & $\begin{array}{l}\text { ard finan- } \\
\text { - Upward } \\
\text { s, 3-Con- }\end{array}$ \\
\hline $\begin{array}{l}\text { TABLE } 3 \\
\text { Means of independent } \\
\text { variables across the }\end{array}$ & $\begin{array}{l}\text { Finan } \\
\text { across }\end{array}$ & & $\begin{array}{l}\text { The inte } \\
\text { of family }\end{array}$ & & Age & $\begin{array}{l}\text { House- } \\
\text { hold size }\end{array}$ \\
\hline across generations) & 0 & Mean & & 2,89 & 56,11 & 3,00 \\
\hline & & Std. Deviation & & 037 & 10,276 & 1,512 \\
\hline & 1 & Mean & & 2,50 & 55,54 & 2,83 \\
\hline & & Std. Deviation & & 966 & 12,158 & 1,409 \\
\hline & 2 & Mean & & 3,32 & 54,35 & 3,11 \\
\hline & & Std. Deviation & & 984 & 10,934 & 1,665 \\
\hline & 3 & Mean & & 3,03 & 52,63 & 2,49 \\
\hline & & Std. Deviation & & 850 & 7,924 & 1,141 \\
\hline & Total & Mean & & 2,90 & 55,36 & 2,95 \\
\hline & & Std. Deviation & & 031 & 10,699 & 1,504 \\
\hline
\end{tabular}

0 - No financial transfer between generations, 1 - Downward financial transfer from dependent parents to adult children, 2 - Upward financial transfer from adult children to dependent parents, 3 - Concurrent transfer

We now turn to our main question: the determinants of the financial flows within the observed dyads, i.e., social home care recipients and their informal caregivers. For this purpose, we have used a multinomial regression model. The parameters for the quality of the whole model indicate that a multinomial regression model fits the data $\left(\chi^{2}=1171.932, p=0.625\right.$; intercept only vs the final model: $\chi^{2}=85.133, p=0.0001$ ). 


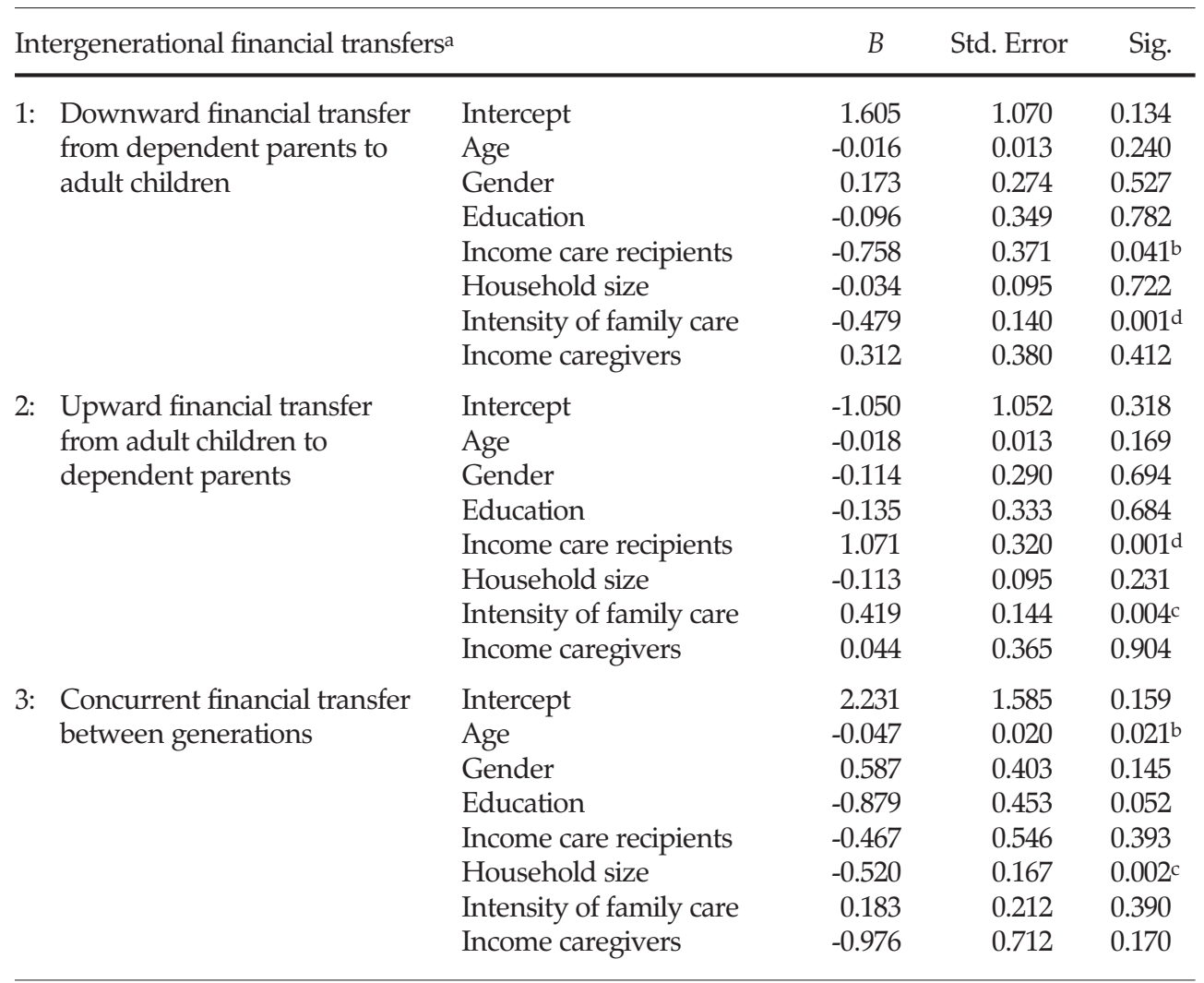

a The reference category is 0 (no financial transfers between generations); ${ }^{b}$ sig. $5 \%$; ${ }^{c}$ sig. $1 \%$; d sig. $0.1 \%$

(1) TABLE 4 Multinomial regression model with intergenerational financial trasfers as dependent variable
All regression parameters were obtained by comparing the category 0 (no financial transfers between generations) against each of the three remaining categories $(1=$ downward financial transfer from dependent parents to adult children, $2=$ upward financial transfer from adult children to dependent parents and $3=$ concurrent financial transfer between generations) (Table 4). Only two independent variables influence downward financial transfers from dependent parents to adult children caregivers, namely, the financial status of the elderly person's household and the amount of family care provided by the children. The elderly are significantly less likely to make downward financial transfers if they report difficulties managing with their income. Also, the greater the amount of care provided by family carers, the less likely downward financial transfer is.

The same independent variables influence upward financial transfers from adult children caregivers to dependent parents, namely, the financial status of the elderly person's household and the amount of family care provided by the children. Adult children are significantly more likely to contribute finan- 
DRUŠ. ISTRAŽ. ZAGREB GOD. 27 (2018), BR. 1 STR. $27-46$

HLEBEC, V., FILIPOVIČ HRAST, $M$.:

CHARACTERISTICS... cially to the care of older people if the older people report difficulties managing with their income. Similarly, the greater the amount of care provided by family carers, the more likely upward financial transfer is. This latter might indicate that the elderly have a greater need for informal as well as formal care, which also means higher costs of formal care and consequently the need for financial aid from children to their parents for this care.

Age, gender and education had no influence on financial transfers. It is interesting to note that the income of the caregivers had no impact on financial transfers, contrary to the findings of Fritzell and Lennartsson (2005) and Lennartsson et al. (2010) that financial transfers are more common within families with higher socioeconomic status. This might be due to the specifics of financial flows observed in the article, i.e., helping financially for the payment of social home care services. It indicates that payment for services by children is strictly determined by the needs of the elderly. In cases where perhaps the family cannot meet this need, no services are used.

Concurrent financial transfer differs somewhat from other models, which points to an interesting and potentially systematic difference in understanding how such direct concurrent financial transfers function within families and what influences them. However, the interpretation must be cautious due to the small number of included cases.

Concurrent financial transfer is significantly influenced by a different set of independent variables, namely, only by caregivers' characteristics, such as their age, education and household size. With family caregivers' increasing age, concurrent financial transfers become significantly less likely than no financial transfers between generations. Likewise, with higher education of the caregivers, concurrent financial transfer is significantly less likely than the absence of financial transfers. Similarly, with increasing size of the caregiver's household, concurrent financial transfer is significantly less likely than no financial transfers between generations. It is interesting to note that for concurrent transfers, the incomes of the caregiver and the care recipient are not important, indicating that reciprocal relations are linked to other characteristics and are not income-related in contrast to the case of the downward and upward financial transfers.

\section{CONCLUSIONS}

In our study, we investigated financial transfers in dyads of informal carers and social home care users based on a survey carried out in Slovenia in 2013. Our findings indicated high financial flows between generations as approximately one fifth of informal carers reported upward financial flows and the 
DRUŠ. ISTRAŽ. ZAGREB GOD. 27 (2018), BR. 1, STR. $27-46$

HLEBEC, V., FILIPOVIČ HRAST, M.:

CHARACTERISTICS... same proportion reported downward financial flows. There was no predominance of the downward financial flows usually found in this research. This is different from the findings of the research where general population samples were used and indicates a potential specific of the observed subgroup of older people (see Albertini et al., 2007; Deindel \& Brandt, 2011). However, hypothesis 1 , where we anticipated stronger upward than downward flows, was not confirmed as downward financial flows were, only marginally, more likely than upward financial flows (21.5\% vs $20.2 \%$ ). A stronger upward flow is most likely specific to the group observed; specifically, the elderly in great need of care and older people who use formal services. Among the social home care users, therefore, a significant proportion of the elderly receive financial transfers from their children in order to cope with the cost of care. This indicates that social home care services represent a financial burden not only on the elderly but quite often on the wider family. This finding has important policy implications as it puts forward the issue of financial accessibility of social home care services for the most vulnerable. One needs to also keep in mind that part of the most vulnerable group within the elderly, who are potentially in great need of care, may not even decide to use social home care services due to costs. Addressing this issue of financial accessibility of services is of vital importance in the development of social home care services in the region as research has indicated the unmet needs of the elderly are high in Eastern European countries, and these countries also seem to have the least success in ensuring longterm care for socially excluded older people (Srakar, Filipovič Hrast, Hlebec, \& Majcen, 2015).

Regression models have shown that the financial status of the care recipients is largely associated with the upward and downward transfers, for when the elderly are poor, there is less likelihood of downward financial flows and a higher probability of upward financial flows. This confirms hypothesis 3 and corresponds to the findings of Deindl and Brandt (2011) on how a generous welfare state enables downward transfers. On the other hand, the larger amount of care did not increase downward financial flows or concurrent flows, contrary to our hypothesis (H4). It seems that the specific circumstances of higher need existing among social home care users indicate that in cases where more care is provided by informal caregivers, the ability of older people to reciprocate is diminished, potentially also due to the existing formal costs of care.

This potentially raises issues of balance in intergenerational relations in cases of high care needs. Also, the fact that a large proportion of children help their parents financially with payment for formal care services raises the issue of the 
DRUŠ. ISTRAŽ. ZAGREB GOD. 27 (2018), BR. 1 STR. 27-46

HLEBEC, V., FILIPOVIČ HRAST, $M$.:

CHARACTERISTICS... 'sandwich' generation, which needs to provide money for elderly parents as well as financially aid younger generations. We have not tested this in our article as we unfortunately have no data on additional financial transfers of interviewed family carers to their children. However, these flows seem to be quite common in the region, where middle-aged parents provide financial support to younger generations, especially in achieving housing independence (see e.g., Cirman, 2006). As Železná (2016) suggested, caring responsibilities tend to accumulate rather than compete with one another and therefore could represent a potential risk of overburden for those who have a general tendency to care, and according to some estimates (see Friedman et al., 2015), over 30\% of individuals with living parents and adult children provide transfers to two generations.

We are aware of some limitations of our study. First of all, we did not focus on the whole population of older people and their family carers. Our study surveyed only a subpopulation of older people that use social home care together with family care. This sub-population in Slovenia tends to be better off in terms of income, but also tends to lack in complexity of family networks (no spouse, children living outside the household of care recipients) as given by Hlebec et al. (2016). Furthermore, the fact that the data collection method was self-administration led to missing values, which deflated the final sample in multivariate regression models. We compared the univariate distributions of each independent variable in the initial and final samples and we did not find significant deviations. We also tested several multivariate models, finally deciding on the model presented in the paper, as it was the most parsimonious. Also, income was assessed using a proxy, and this may be a disadvantage, but it was nevertheless used in other studies as well (e.g. Litwin et al., 2008). Additionally, another important limitation of our study is that we have not observed the whole network of carers that provide care to the elderly and their division of responsibilities. The number of siblings is also shown to influence financial transfers as siblings compete for parental resources (see Brandt \& Deindl, 2013).

As we hypothesised (H2), the share of concurrent transfers was the smallest, representing only $7.7 \%$. Our findings also indicated that concurrent financial flows seem to function differently, i.e., they were not related to the income of either the elderly person or of the informal carer, in contrast to the upward or downward flows, and were more likely in cases when the family carer was younger, single and lower educated. These findings therefore contribute to understanding transfer patterns of concurrent giving and receiving in the parent-child relationship. 
DRUŠ. ISTRAŽ. ZAGREB GOD. 27 (2018), BR. 1, STR. $27-46$

HLEBEC, V., FILIPOVIČ HRAST, M.:

CHARACTERISTICS...
There are some shortcomings in our analysis that warrant a cautious interpretation of the main results, especially for the findings on concurrent financial flows. There were only a small number of dyads reporting concurrent flows, which was a disadvantage for our analysis. Also, the quantitative measurement of transfers might have been hindered, especially in multigenerational households, where transfers may be numerous, but also such a self-evident part of everyday life that respondents might not report them. Therefore, concurrent transfers need a more detailed, in-depth study. Furthermore, our study focusses specifically on financial transfers that are linked to costs of social home care and within this specific population, and therefore, it only partially gives answers regarding general financial transfers among the childparent dyads in cases of mixed care. However, we feel that it contributes relevantly to the literature on financial transfers, which, however, need to be additionally researched in these specific circumstances. The relevant policy implications are in pointing to the issue of family transfers that aid in payment of social home care and determinants of these transfers. Especially important is recognition of the dual burden of carers, as they can provide care as well as financial support, which would both need to be recognised in supportive policies for family carers. As social home care in Slovenia, despite the possibility of subsidy, represents a burden for the users and their families, this emphasises that policy makers need to take into account the potential financial difficulties of the payment of this service for the user as well as their informal carers. This could be addressed also by changing the census for receiving subsidies for the services, as well as different gradients of subsidies according to the family income.

\section{REFERENCES}

Albertini, M., Kohli, M., \& Vogel, C. (2007). Intergenerational transfers of time and money in European families: Common patterns - different regimes? Journal of European Social Policy, 17(4), 319-334. https://doi. org/10.1177/0958928707081068

Andrén, S., \& Elmståhl, S. (2007). Relationships between income, subjective health and caregiver burden in caregivers of people with dementia in group living care: A cross-sectional community-based study. Nursing Studies, 44(3), 435-446. https://doi.org/10.1016/j.ijnurstu.20 06.08.016

Bengtson, V. L., \& Oyama, P. S. (2007). Intergenerational solidarity: Strengthening economic and social ties. New York: United Nations Headquarters.

Bengtson, V. L., \& Roberts, R. E. L. (1991). Intergenerational solidarity in aging families: An example of formal theory construction. Journal of Marriage and Family, 53(4), 856-870. https://doi.org/10.2307/ 352993 
DRUŠ. ISTRAŽ. ZAGREB STR. $27-46$ CHARACTERISTICS. GOD. 27 (2018), BR. 1

\section{HLEBEC, V., FILIPOVIC HRAST, M.:}

Bettio, F., \& Plantenga, J. (2004). Comparing care regimes in Europe. Feminist Economics, 10(1), 85-113. https://doi.org/10.1080/13545700420 00198245

Björnberg, U., \& Ekbrand, H. (2008). Financial and practical kin support in Sweden: Normative guidelines and practice. Journal of Comparative Family Studies, 39(1), 73-95.

Brandt, M., \& Deindl, C. (2013). Intergenerational transfers to adult children in Europe: Do social policies matter? Journal of Marriage and Family, 75(1), 235-251. https://doi.org/10.1111/j.1741-3737.2012.01028.x

Brandt, M., Haberkern, K., \& Szydlik, M. (2009). Intergenerational help and care in Europe. European Sociological Review, 25(5), 558-601. https://doi.org/10.1093/esr/jen076

Broese van Groenou, M., Glaser, K., Tomassini, C., \& Jacobs, T. (2006). Socio-economic status differences in older people's use of informal and formal help: A comparison of four European countries. Ageing E Society, 26(5), 745-766. https://doi.org/10.1017/S0144686X06005241

Carretero, S., Garcés, J., Ródenas, F., \& Sanjosé, V. (2008). The informal caregiver's burden of dependent people: Theory and empirical review. Archives of Gerontology and Geriatrics, 49(1), 74-79. https://doi. org/10.1016/j.archger.2008.05.004

Cirman, A. (2006). Kako dosegljiva so stanovanja za slovenska gospodinjstva? [How accessible are the dwellings for Slovenian households?]. In S. Mandič, \& A. Cirman (Eds.), Stanovanje v Sloveniji 2005 [Housing in Slovenia 2005], (pp. 55-70). Ljubljana: Fakulteta za družbene vede.

Deindl, C., \& Brandt, M. (2011). Financial support and practical help between older parents and their middle-aged children in Europe. Ageing \& Society, 31(4), 645-662. https://doi.org/10.1017/S0144686X 10001212

Dobrotić, I. (2016). Razvoj i poteškoće sustava skrbi za starije osobe u Republici Hrvatskoj [Development and difficulties of the eldercare system in Croatia]. Društvena istraživanja, 25(1), 21-42.

Filipovič Hrast, M., Hlebec, V., \& Kavčič, M. (2012). The social exclusion of the elderly: A mixed-methods study in Slovenia. Sociologický časopis, 48(6), 1051-1074.

Friedman, E. M., Park, S. S., \& Weimers, E. E. (2015). New estimates of the sandwich generation in the 2013 panel study of income dynamics. The Gerontologist, 57(2), 191-196. https://doi.org/10.1093/geront/ gnv080

Fritzell, J., \& Lennartsson, C. (2005). Financial transfers between generations in Sweden. Ageing \& Society, 25(6), 397-414. https://doi.org/ 10.1017/S0144686X04003150

Grundy, E. (2005). Reciprocity in relationships: Socio-economic and health influences on intergenerational exchanges between Third Age parents and their adult children in Great Britain. The British Journal of Sociology, 56(2), 233-255. https://doi.org/10.1111/j.1468-4446. 2005.00057.x 
DRUŠ. ISTRAŽ. ZAGREB GOD. 27 (2018), BR. 1, STR. $27-46$

HLEBEC, V., FILIPOVIČ HRAST, M.:

CHARACTERISTICS... nion and children's care of older parents in 11 European countries. Ageing \& Society, 30(2), 299-323. https://doi.org/10.1017/S0144686X 09990316

Hlebec, V. (2010). Oskrba starih med državo in družino: oskrba na do$\mathrm{mu}$. [Care for older people between the welfare state and family]. Teorija in praksa, 47(4), 765-785.

Hlebec, V. (2012). Contextual factors of home care utilization in Slovenia. Zdravstveno Varstvo, 51(2), 120-127. https://doi.org/10.2478/v10 152-012-0014-Z

Hlebec, V. (2014). Individual and contextual determinants of social homecare usage in Slovenia / Dispozicijski in kontekstualni dejavniki uporabe socialne oskrbe na domu. Zdravstveno Varstvo, 53(4), 311-317. https://doi.org/10.2478/sjph-2014-0034

Hlebec, V., \& Filipovič Hrast, M. (2016). Influence of contextual and organisational factors on combining informal and formal care for older people: Slovenian case. Research on Ageing and Social Policy, 4(2), 30-54. https://doi.org/10.17583/rasp.2016.1835

Hlebec, V., \& Rakar, T. (2017). Ageing policies in Slovenia before and after Austerity. In L. Tomczyk, \& A. Klimezuk (Eds.), Selected contemporary challenges of ageing policy (pp. 27-51). Krakow: Uniwersytet Pedagogiezny w Krakowie. https://doi.org/10.24917/9788380840911.2

Hlebec, V., Nagode, M., \& Filipovič Hrast, M. (2014a). Care for older people between state and family: Care patterns among social home care users. Teorija in praksa: revija za družbena vprašanja, 51(5), 886-903.

Hlebec, V., Nagode, M., \& Filipovič Hrast, M. (2014b). Kakovost socialne oskrbe na domu: vrednotenje, podatki in priporočila [Quality of social home care in Slovenia: Evaluation, data and recommendations]. Ljubljana: Fakulteta za družbene vede, Založba FDV.

Hlebec, V., Srakar, A., \& Majcen, B. (2016). Care for the elderly in Slovenia: A combination of informal and formal care. Revija za socijalnu politiku, 23(2), 159-179. https://doi.org/10.3935/rsp.v23i2.1317

Hlebec, V., Filipovič Hrast, M., Kump, S., Jelenc Krašovec, S., Pahor, M., \& Domanjko, B. (2012). Medgeneracijska solidarnost v Sloveniji [ntergenerational solidarity in Slovenia]. Ljubljana: Fakulteta za družbene vede.

Igel, C., Brandt, M., Haberkern, K., \& Szydlik, M. (2009). Specialization between family and state intergenerational time transfers in Western Europe. Journal of Comparative Family Studies, 40(2), 203-226.

Jacobs, M. T., Broese van Groenou, M. I., de Boer, A. H., \& Deeg, D. J. H. (2014). Individual determinants of task division in older adults' mixed care networks. Health $\mathcal{E}$ Social Care in the Community, 22(1), 57-66. https://doi.org/10.1111/hsc.12061

Kohli, M., \& Künemund, H. (2003). Intergenerational transfers in the family: What motivates giving? In V. L. Bengtson, \& A. Lowenstein (Eds.), Global ageing and challenges to families (pp. 123-142). New York, Aldine de Gruyter.

Künemund, H. (2008). Intergenerational relations within the family and the state. In C. Saraceno (Ed.), Families, ageing and social policy: Intergenerational solidarity in European welfare states (pp. 105-122). Cheltenham, UK: Edward Elgar Publishing. https://doi.org/10.4337/9781848 445147.00011 
DRUŠ. ISTRAŽ. ZAGREB GOD. 27 (2018), BR. 1 STR. $27-46$

\section{HLEBEC, V., FILIPOVIC HRAST, $M$.:} CHARACTERISTICS.
Leitner, S. (2003). Varieties of familialism: The caring function of the family in comparative perspective. European Societies, 5(4), 353-375. https://doi.org/10.1080/1461669032000127642

Lennartsson, C., Silverstein, M., \& Fritzell, J. (2010). Time-for-money exchanges between older and younger generations in Swedish families. Journal of Family Issues, 31(2), 189-210. https://doi.org/10.1177/ $0192513 \times 09344158$

Leopold, T., \& Raab, M. (2011). Short-term reciprocity in late parent-child relationships. Journal of Marriage and Family, 73(1), 105-119. https://doi. org/10.1111/j.1741-3737.2010.00792.x

Litwin, H., Vogel, C., Künemund, H., \& Kohli, M. (2008). The balance of intergenerational exchange: Correlates of net transfers in Germany and Israel. European Journal of Ageing, 5(2), 91-102. https://doi.org/ 10.1007/s10433-008-0079-3

Lowenstein, A., Katz, R., \& Gur-Yaish, N. (2007). Reciprocity in parent-child exchange and life satisfaction among elderly: A cross-national perspective. Journal of Social Issues, 63(4), 865-883. https://doi.org/10. 1111/j.1540-4560.2007.00541.x

Motel-Klingebiel, A., Tesch-Roemer, C., \& Von Kondratowitz, H.-J. (2005). Welfare states do not crowd out the family: Evidence for mixed responsibility from comparative analyses. Ageing $\mathcal{E}$ Society, 25(6), 863-882. https://doi.org/10.1017/S0144686X05003971

Mudrazija, S. (2014). The balance of intergenerational family transfers: A life-cycle perspective. European Journal of Ageing, 11(3), 249-259. https://doi.org/10.1007/s10433-013-0302-8

Mudrazija, S. (2016). Public transfers and the balance of intergenerational family support in Europe. European Societies, 18(4), 336-358. https://doi.org/10.1080/14616696.2016.1207792

Nagode, M., Lebar, L., Kovač, N., \& Vidrih, N. (2016). Izvajanje pomoči na domu: analiza stanja v letu 2015. [Social home care: Data in 2015]. Inštitut Republike Slovenije za socialno varstvo. Available at http://www. irssv.si/upload2/Izvajanje PND za leto 2015.pdf

Saraceno, C. (2010). Social inequalities in facing old-age dependency: A bi-generational perspective. Journal of European Social Policy, 20(1), 32-44. https://doi.org/10.1177/0958928709352540

Saraceno, C., \& Keck, W. (2010). Can we identify intergenerational policy regimes in Europe? European Societies, 12(5), 675-696. https://doi. org/10.1080/14616696.2010.483006

Silverstein, M., \& Bengtson, V. L. (1997). Intergenerational solidarity and the structure of adult child-parent relationships in American families. American Journal of Sociology, 103(2), 429-460. https://doi.org/ $10.1086 / 231213$

Silverstein, M., Parrott, T. M., \& Bengtson, V. L. (1995). Factors that predispose middle-aged sons and daughters to provide social support to older parents. Journal of Marriage and the Family, 57(2), 465-475. https://doi.org/10.2307/353699

Silverstein, M., Conroy, S. J., Wang, H., Giarrusso, R., \& Bengtson, V. L. (2002). Reciprocity in parent-child relations over the adult life course. Journals of Gerontology: Series B, 57(1), S3-S13. 
DRUŠ. ISTRAŽ. ZAGREB GOD. 27 (2018), BR. 1, STR. $27-46$

HLEBEC, V., FILIPOVIČ HRAST, M.:

CHARACTERISTICS...
Srakar, A., Filipovič Hrast, M., Hlebec, V., \& Majcen, B. (2015). Social exclusion, welfare regime and unmet long-term care need: Evidence from SHARE. In A. Börsch-Supan, T. Kneip, H. Litwin, M. Myck, \& G. Weber (Eds.), Ageing in Europe: Supporting Policies for an Inclusive Society (pp. 189-198). Berlin; Boston: W. de Gruyter. https://doi.org/ 10.1515/9783110444414-019

Szydlik, M. (2008). Intergenerational solidarity and conflict. Journal of Comparative Family Studies, 97-114.

Železná, L. (2016). Care-giving to grandchildren and elderly parents: Role conflict or family solidarity? Ageing \& Society, 1-21. https://doi. org/10.1017/S0144686X16001434

\section{Karakteristike i odrednice međugeneracijskih financijskih transfera unutar obitelii koje se koriste mješovitom skrbi za starije osobe}

Valentina HLEBEC, Maša FILIPOVIČ HRAST

Fakultet društvenih znanosti, Ljubliana

Pružanje skrbi starijim roditelïma ili roditelïma partnera važan je dio međugeneracijske solidarnosti unutar obitelii, osobito u zemljama u kojima se dugoročni sustav skrbi zasniva pretežno na obiteljskoj skrbi. Međutim, u sustavima mješovite skrbi potrebnu skrb zajedno pružaju članovi obitelii i pružatelii formalne skrbi. Osim toga, odrasla će djeca možda morati i financijski pomagati svojim roditelijima, posebno zbog financijskoga tereta što ga formalna skrb nameće starijim osobama. Rad se temelii na Slovenskom nacionalnom istraživanju korisnika socijalne skrbi i članova njihovih obitelii. Podaci su prikupljeni 2013. godine radi promatranja karakteristika i odrednica međugeneracijskih financijskih transfera u obiteljima koje se koriste mješovitom skrbi, unutar dijada koje uključuju primatelja skrbi i obiteljskoga skrbnika. Rezultati pokazuju da postoji osjetna financijska razmjena između promatranih dijada. Nadalje, odrednice važne za financijske tijekove prema gore (starijem roditeliu) i prema dolje (od starijega roditelia) jesu prihod starijih osoba i iznos primljene skrbi, dok se kod istodobnih tijekova sredstava one razlikuju; glavne su odrednice starost pružatelja skrbi, veličina kućanstva i obrazovanje.

Ključne riječi: međugeneracijska solidarnost, obiteli, financijski transferi, socijalna skrb

\section{(c) (i) $(9)$}

Međunarodna licenca / International License:

Creative Commons Attribution-NonCommercial-NoDerivatives 4.0. 